\title{
Uranium affects growth, sporulation, biomass and leaf-litter decom- position by aquatic hyphomycetes
}

\author{
Melissa Bergmann* and Manuel A.S. Graça \\ Mare - Marine and Environmental Sciences Centre, Department of Life Sciences, University of Coimbra, \\ 3001-456, Coimbra, Portugal. \\ * Corresponding author: mbergmann@student.uc.pt
}

Received: 05/12/18 Accepted: 03/07/19

\begin{abstract}
Uranium affects growth, sporulation, biomass and leaf-litter decomposition by aquatic hyphomycetes

Contamination by uranium mining activity may lead to harmful effects on freshwater biota, and can affect the reproduction, activity and diversity of aquatic fungi. Here we investigate uranium inhibition of fungal growth in solid medium, using (1) four species of aquatic hyphomycetes and (2) six strains of Heliscus lugdunensis. We also measured (3) fungal sporulation, (4) fungal biomass and (5) litter decomposition in laboratory microcosms exposed to uranium. The uranium concentration causing $50 \%$ growth inhibition ( $\mathrm{EC}_{50}$ ) ranged from 12.5 to $45 \mathrm{mg} / \mathrm{l}$, with Articulospora tetracladia the most sensitive and Varicosporium elodeae the most tolerant species. Strains sampled from reference and uranium polluted waters differed in their tolerance, but the tolerance was independent of the uranium concentration in the streams where fungi were isolated. The $\mathrm{EC}_{50}$ for the six strains ranged from 9 to $25 \mathrm{mg} / \mathrm{l}$. Sporulation was inhibited in microcosms at uranium concentrations $\geq 1 \mathrm{mg} / 1$, and the minimum concentration inhibiting litter decomposition and biomass standing crop over 24 days was $16 \mathrm{mg} / \mathrm{l}$. Leaf-litter exposed to uranium accumulated the metal up to $89 \mathrm{mg} / \mathrm{kg}$ (in $262 \mathrm{mg} / \mathrm{l} \mathrm{of} \mathrm{U}$ ). Overall, the amount of uranium in many streams receiving discharges from abandoned or recovered mining sites is high enough to impair fitness of some aquatic hyphomycete species.
\end{abstract}

Key words: metal pollution tolerance; fungal reproduction; mining effects

\section{RESUMO}

Urânio afeta o crescimento, esporulação, biomassa e decomposição de detritos foliares por hifomicetos aquáticos

A contaminação das águas superficiais pela mineração de urânio pode levar a efeitos nocivos à biota aquática, interferindo na reprodução, na atividade e na diversidade dos fungos aquáticos. Os efeitos do urânio no crescimento dos hifomicetos aquáticos em meio sólido foram investigados em (1) quatro espécies de fungos e (2) seis estirpes de Heliscus lugdunensis. Também foram investigados os efeitos na (3) esporulação, (4) biomassa e (5) decomposição de detritos foliares em microcosmos contaminados com urânio. As concentrações de urânio que causaram $50 \%$ de inibição do crescimento (CE 50) estiveram entre 12.5 e $45 \mathrm{mg} / \mathrm{l}$, sendo Articulospora tetracladia a espécie mais sensivel e Varicosporium elodeae a mais tolerante. As estirpes amostradas em locais poluidos e de referência diferiram em seus graus de tolerância, mas esta foi independente da concentração de urânio nos locais onde os fungos foram isolados. A concentração de efeito (CE50) para as seis estirpes variou de 9 para $25 \mathrm{mg} / \mathrm{l}$. Nos microcosmos, a esporulação foi inibida em concentrações de urânio $\geq 1 \mathrm{mg} / \mathrm{l}$, enquanto que a concentração mínima inibitória da decomposição dos detritos foliares e da biomassa durante 24 dias foi de $16 \mathrm{mg} / \mathrm{l}$. Os detritos foliares expostos a urânio acumularam até $89 \mathrm{mg} / \mathrm{kg}$ na concentração de $262 \mathrm{mg} / \mathrm{l}$. A quantidade de urânio em águas que recebem metais de minas abandonadas ou em recuperação pode ser suficientemente elevada para afetar as atividades biológicas e $o$ desempenho dos hifomicetos aquáticos nos ecossistemas fluviais.

Palavras chave: tolerância a metais, reprodução fúngica, mineração 


\section{INTRODUCTION}

Uranium is naturally found on Earth mainly as uranium oxides $\mathrm{UO}_{2}, \mathrm{U}_{2} \mathrm{O}_{5}$. Mining may release uranium and other metals in soil and waters, potentially affecting the aquatic biota. Uranium mining in Portugal was an important activity until the end of the 1990s and there are nowadays $\sim 60$ abandoned uranium mines. Although many mines were subjected to requalification, which significantly reduced the uranium leaching into freshwaters, there are still low uranium contamination levels in these sites (Pereira et al., 2014).

Given the high energy demands for a growing human population and the need to decrease $\mathrm{C}$ emission to meet the Paris Agreement goals (United Nations, 2015), it is likely that mining for uranium will increase worldwide in the upcoming decades. This may result in water contamination from uranium and deteriorations in environmental quality as suggested by evidence from field and laboratory studies. For instance, stream dwelling invertebrates exposed to uranium had a decreased growth (Muscatello \& Liber, 2009; Bergmann et al., 2018), food ingestion (Gonçalves et al., 2011) and altered enzymatic activities (Hyne et al., 1993; Tagliaferro et al., 2018).

Although information on uranium toxicity to aquatic invertebrates is available, comparatively little is known about its effects on aquatic hyphomycetes, despite their functional key role in streams. Aquatic hyphomycetes colonise and decompose plant debris, playing an important role in the energy transfer from dead organic matter to higher trophic levels in streams (Bärlocher, 2012; Maharning \& Bärlocher, 1996). They also improve the nutrient content and palatability of the leaves for consumers (Chung \& Suberkropp, 2009; Suberkropp \& Arsuffi, 1984).

Some species of aquatic hyphomycetes tolerate and are able to sporulate in metal polluted streams (Krauss et al., 2001). However, metal exposure may depress sporulation at concentrations below the threshold, causing reductions in fungal biomass and their functional role in litter decomposition (Duarte et al., 2004; Medeiros et al., 2008, 2010). Processes such as the complexation of -SH compounds with metals, biosorption, bioaccumulation, precipitation and biominerali- sation or genetic adaptation may be involved in fungal resistance to metals (Baldrian \& Gabriel, 2002; Braha et al., 2007; Fomina et al., 2007; Miersch et al., 1997).

Intraspecific differences in metal tolerance have been reported. Such differences in strains isolated from polluted or non-polluted streams include strain-specific accumulation and conidia size variations (Braha et al., 2007; Pradhan et al., 2014, 2015). The adaptation of the strains to contaminants allow fungal assemblages to retain the capability to perform their functional role in litter decomposition, but fungal metal biosorption may decrease leaf litter quality for consumers (Ferreira et al., 2010; Gonçalves et al., 2011).

Here we investigated the tolerance of aquatic hyphomycetes to uranium and asked three questions: (a) Do aquatic hyphomycetes differ in their tolerance to uranium? (2) Are there intraspecific differences in aquatic hyphomycete species in their tolerance to uranium pollution? and (3) Which biological/functional fungal parameters are more sensitive to uranium? To address these questions, we measured increased uranium concentration effects on fungal growth, sporulation, biomass and leaf-litter decomposition. We used four species of aquatic hyphomycetes sampled from uncontaminated stream and six strains of Heliscus lugdunensis sampled from the reference and uranium contaminated streams.

\section{MATERIALS AND METHODS}

\section{Fungal isolation}

We used four aquatic hyphomycete species isolated from reference streams in Central Portugal (Múceres N 40 32' 01"; W 08 09’ 15", pH 6.9, $0.35 \mu \mathrm{g} / \mathrm{l} \mathrm{U}$ in water and $1.0 \mathrm{mg} / \mathrm{kg} \mathrm{U}$ in sediments). The isolated species were Articulospora tetracladia Ingold, Tricladia splendens Ingold, Varicosporium elodeae Kegel, Heliscus lugdunensis Saac. We also used six strains of a ubiquitous aquatic hyphomycete $H$. lugdunensis $S a c c$, five of which were sampled from uranium contaminated sites in Central Portugal (courtesy of Seena Sahadevan; Table S1, available at http://www.limnetica.net/en/limnetica).

Fungi were isolated from leaf-litter collected 
at a reference site (Múceres). The litter was maintained in plastic vessels in the laboratory with stream water $(\sim 10 \mathrm{~L})$ under strong aeration for 10 days. Samples of water taken from the vessels were observed under a binocular microscope and the suspended spores were picked up with an eyelash mounted in a needle and transferred to an agar-based medium (see below) for germination (Descals, 2005). Mycelium formed from colonies developed in the agar plates were individually cut and transferred to new media in plates (pure culture plates). Cuts from pure cultures were transferred to Erlenmeyer flasks with distilled water on an orbital shaker (48 h) to allow sporulation to confirm the identification. Pure fungal cultures were maintained in malt extract agar (1.5 $\%$; distilled water) in Petri dishes at $15 \pm 1{ }^{\circ} \mathrm{C}$ and 12-h light/12-h dark conditions for $\sim 15$ days before use in the assays.

\section{Fungal growth inhibition}

Two experiments were run. The first we measured growth inhibition in four species of aquatic hyphomycetes exposed to six concentrations of uranyl nitrate solution $\left(\mathrm{UO}_{2}\left(\mathrm{NO}_{3}\right)_{2}\right)$ in malt extract agar (MEA, $1.5 \%$ ): 0; 0.004; 0.064; 1.024; 16.384 and $262 \mathrm{mg} / \mathrm{l}$. The final design consisted of 72 Petri dishes (4 fungal species $\times 6$ $\mathrm{U}$ concentrations $\times 3$ replicates). In a second experiment we measured growth inhibition in six strains of $H$. lugdunensis. In this case, the final design consisted of 108 Petri dishes ( 6 strains $\times 6$ $\mathrm{U}$ concentrations $\times 3$ replicates). Plugs $(5 \mathrm{~mm})$ of pure fungal cultures were placed on the centre of each Petri dish. The colony average diameter (mm) was measured every 2 days for 20 days $(n=$ 10 measurements). The individual growth was expressed in daily area $\left(\mathrm{mm}^{2}\right)$ increase. The colony morphology (colour, size, boundary shape) in each treatment was also recorded.

\section{Fungal sporulation, fungal biomass in leaves and leaf-litter decomposition}

We used the four fungal species isolated from the reference stream for this assay. Leaf discs were cut with a cork-borer (12 $\mathrm{mm}$ diameter) from the senescent leaves of Alnus glutinosa collected in
Mondego River Park (Coimbra, Portugal) in autumn, 2016. Sets of seven discs were autoclaved $\left(120^{\circ} \mathrm{C}, 20 \mathrm{~min}\right)$, oven-dried $\left(105^{\circ} \mathrm{C}, 48\right.$ h), and weighed $( \pm 0.1 \mathrm{mg}$ ) to obtain initial dry mass (DMi). Leaf discs were placed in $250-\mathrm{mL}$ Erlenmeyer flasks containing $30 \mathrm{~mL}$ of sterile distilled water (18 flaks for each species and 18 flaks as controls, with no inoculation; 90 flasks in total). Five $5-\mathrm{mm}$ plugs from pure cultures were used as inoculum. The flasks were maintained for six days on an orbital shaker, with a change of water by Day three. By Day six, the plugs and the water were removed, and uranium solutions were added (from 0 to $262 \mathrm{mg} / \mathrm{l} \mathrm{U}$ as above; 3 replicates/treatment). The media was changed every three days. The $\mathrm{pH}$ was measured at the beginning and at the end of the three days. By Day 24 the leaf discs were removed, freeze-dried weighed and stored at $-20^{\circ} \mathrm{C}$.

The spore suspensions from the microcosms retrieved every three days were transferred to $500-\mathrm{mL}$ plastic bottles with $2 \mathrm{~mL}$ of $37 \%$ formalin for preservation. By Day 25, $100 \mu 1$ of $0.5 \%$ Triton X-100 solution were added to the spore suspension and stirred. An aliquot $(10-100 \mathrm{~mL})$ was filtered in a $25 \mathrm{~mm} \varnothing, 5-\mu \mathrm{m}$ pore size membrane (Sartorius Stedim Biotech GmbH, Göttingen Germany) and stained with $0.05 \%$ cotton blue in $60 \%$ acid lactic. Spores were counted under a microscope at $200 \times$ in a total of 425 microscope fields. Sporulation was expressed as the number of spores/mg leaf DM (e.g. Bärlocher, 2005):

$$
C=\frac{n \times A}{a \times f} \times \frac{\frac{V}{v}}{D M}
$$

where $\mathrm{C}=$ conidia/mg leaf dry mass; $\mathrm{n}=$ number of spores counted; $\mathrm{A}=$ filter area where spores are retained $\left(489 \mathrm{~mm}^{2}\right) ; \mathrm{a}=$ area of the field of view $\left(0.95 \mathrm{~mm}^{2}\right), \mathrm{f}=$ number of fields counted; $\mathrm{V}=$ total suspension volume; $\mathrm{v}=$ suspension volume filtered; $\mathrm{DM}=$ discs dry mass (mg).

We extracted ergosterol (as a proxy of fungal biomass) from five of the seven lyophilised discs from each microcosm (Gessner, 2005). Discs were weighed $( \pm 0.01 \mathrm{mg})$ and transferred to 
30-mL glass tubes for ergosterol extraction and saponification with $10 \mathrm{~mL} \mathrm{KOH} /$ methanol $(8 \mathrm{~g} / \mathrm{l})$ at $80{ }^{\circ} \mathrm{C}$ for $30 \mathrm{~min}$. The extract was purified (Waters Sep-Pak ${ }^{\odot}$ Vac RC tC18 cartridges; Waters Corp., Milford, MA, USA) and analysed by liquid chromatography at $282 \mathrm{~nm}$ (HPLC; Dionex DX-120, Sunnyvale, CA, USA). The HPLC system was prepared for $100 \%$ methanol in the mobile phase, flow rate $1 \mathrm{~mL} / \mathrm{min}$ and temperature of $33{ }^{\circ} \mathrm{C}$. A factor of $5.5 \mathrm{mg}$ ergosterol $\mathrm{g}^{-1}$ mycelial dry mass was used to convert ergosterol to fungal biomass (Gessner \& Chauvet, 1993). The results were expressed as $\mathrm{mg}$ fungal $\mathrm{DM} / \mathrm{g}$ leaf DM.

Leaf-litter decomposition was computed as the difference between initial and final leaf discs dry mass and expressed as dry mass loss (\%) after 24 days. Eighteen microcosms without fungal inoculation on leaf discs were kept in pure distilled water and were used as a control for leaf mass loss related to factors other than fungal decomposition (e.g. fragmentation by shaking).

\section{Uranium adsorption by leaf dises}

Two discs from each microcosm were retrieved for uranium determinations. The discs were weighed $( \pm 0.01 \mathrm{mg})$, ignited in a muffle (450 ${ }^{\circ} \mathrm{C}, 8 \mathrm{~h}$ ) for ash free dry mass (AFDM) determi-

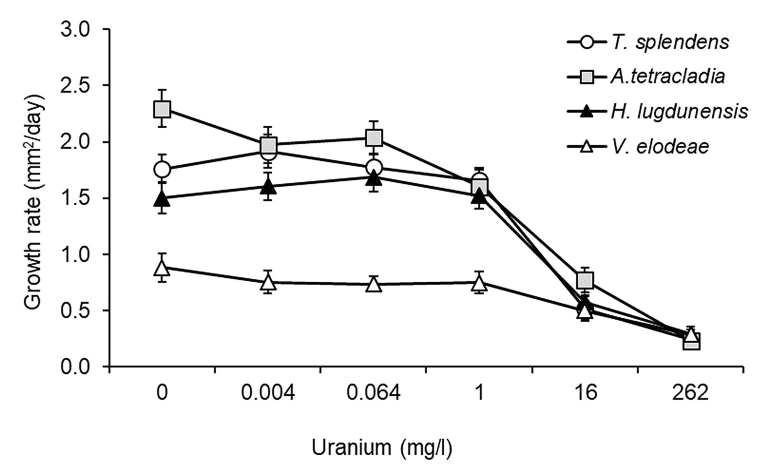

Figure 1. Growth ( $\mathrm{mm}^{2} /$ day) of four hyphomycetes species in agar plates under six uranium concentrations (mean \pm standard deviation; $\mathrm{n}=3$ ). Crescimento ( $\mathrm{mm}^{2} /$ day) de quatro espécies de hifomicetos aquáticos em placas de Petri sob seis concentrações de urânio (média \pm desvio padrão; $n=3$ ). nation, and transferred to falcon tubes with 8 $\mathrm{mL}$ of $2.5 \mathrm{M}$ nitric acid and heated to $60{ }^{\circ} \mathrm{C}$. After $1 \mathrm{~h}$, we added $10 \mathrm{~mL}$ acetic acid and stirred for $2 \mathrm{~min} ; 5 \mathrm{~mL}$ of this solution was transferred to porcelain crucibles for inorganic solvent ignition. The residual was suspended in $7 \mathrm{~mL}$ of $0.005 \%$ nitric acid. Uranium was measured by fluorescence (Bergmann et al., 2018); $0.50 \mathrm{~mL}$ of sample was diluted in $5.0 \mathrm{ml}$ of distilled water and $0.50 \mathrm{ml}$ of the polysilicate solution. Fluorescence was compared to standard curves $(2 ; 10 ; 100$ and $1000 \mu \mathrm{g} / 1$ (Van Loon $\&$ Barefoot, 1989) at $\lambda=530 \mathrm{~nm}$ (Fluorat 02-2M, Lumex).

\section{Data analysis}

Fungal growth inhibition in $10 \%\left(\mathrm{EC}_{10}\right), 20 \%$ $\left(\mathrm{EC}_{20}\right)$ and $50 \%\left(\mathrm{EC}_{50}\right)$ on agar plates at increasing uranium concentrations was estimated using probit analysis (log-transformed concentrations) (OECD, 2003). It was not possible to compute $\mathrm{EC}_{10}$ values for some fungal species and $H$. lugdunensis strains because of large variability (inaccurate confidence intervals). To obtain an indication of the response to metal stress we calculated a tolerance index TI, given by "Growth at a given $[\mathrm{U}] \times 100 /$ Growth in the Control" (Fazli et al., 2015); when no inhibition occurs, TI $=100$; values above 100 indicate stimulation.

Differences in growth between species and between $H$. lugdunensis strains across uranium concentrations were assessed using analysis of variance (two-way ANOVA), after assessing for homoscedasticity (Bartlett test) and normality (Shapiro-Wilk test). We used the Tukey's post hoc test for multiple comparison.

Differences in sporulation, biomass, and leaf-litter decomposition were assessed using one-way ANOVA among concentrations for each species, followed by a Holm-Sidak test for comparison with control groups. When data did not conform to normal distribution, the differences were assessed by Rank ANOVA followed by Dunn's Method for comparison with control groups. Analyses were performed using the software Statistica Statsoft 7 and SigmaStat 3.5 software. 
Table 1. Uranium concentrations (mg/l) inhibiting mycelial growth in $10 \%\left(\mathrm{EC}_{10}\right), 20 \%$ (EC 20$)$ and $50 \%$ (EC50). NC: Not calculated. CI: 95 \% Confidence interval. Concentrações de urânio $(\mathrm{mg} / \mathrm{l})$ que causaram inibição do crescimento micelial em $10 \%$ (CE 10), $20 \%$ (CE 20) e $50 \%$ (CE 50). NC: Não calculado. CI: Intervalo de confiança (95\%).

\begin{tabular}{cccc}
\hline Species & $\mathbf{E C}_{\mathbf{1 0}}(\mathbf{C I})$ & $\mathbf{E C}_{\mathbf{2 0}}(\mathbf{C I})$ & $\mathbf{E C}_{\mathbf{5 0}}(\mathbf{C I})$ \\
\hline T. splendens & $1.2(0.8-1.8)$ & $2.9(2.2-4.1)$ & $21.5(16.0-30.0)$ \\
A. tetracladia & $\mathrm{NC}$ & $0.9(0.7-1.0)$ & $12.5(11.3-13.8)$ \\
H. lugdunensis & $1.1(0.7-1.6)$ & $3.0(2.2-4.0)$ & $25.0(18.5-33.0)$ \\
V. elodeae & $\mathrm{NC}$ & $1.2(1.0-1.5)$ & $45.0(36.3-46.8)$ \\
\hline
\end{tabular}

Table 2. Uranium concentrations (mg/l) inhibiting mycelial growth in $10 \%(\mathrm{EC} 10), 20 \%\left(\mathrm{EC}_{20}\right)$ and $50 \%$ (EC 50$)$ in six strains of H. lugdunensis growing in increasing concentrations. NC: Not calculated; CI: $95 \%$ Confidence interval. Dark grey, light grey and white bands represent respectively the strains more sensitives, with intermediate sensitivity and the most tolerant strain. Concentrações de urânio ( $\mathrm{mg} / \mathrm{l}$ ) que causaram inibição do crescimento micelial em $10 \%$ (CE 10), $20 \%$ (CE 20) e $50 \%$ (CE 50 ) nas seis estirpes de $\mathrm{H}$. lugdunensis. NC: Não calculado; CI: Intervalo de confiança (95\%). As bandas em cinza escuro, cinza claro e branco representam as estirpes mais sensiveis, com sensibilidade intermediária e as mais tolerantes, respectivamente.

\begin{tabular}{ccccc}
\hline Strain & U water $(\boldsymbol{\mu g} / \mathbf{l})$ & $\mathbf{E C} 10(\mathbf{C I})$ & $\mathbf{E C}_{20}(\mathbf{C I})$ & $\mathbf{E C 5 0}(\mathbf{C I})$ \\
\hline $\mathbf{A}$ & $2.68 \pm 0.69$ & $0.7(0.5-1.0)$ & $2.9(1.6-2.4)$ & $15.0(12.5-17.5)$ \\
$\mathbf{B}$ & $3.30 \pm 0.24$ & $\mathrm{NC}$ & $1.5(1.3-1.9)$ & $13.5(12.0-15.5)$ \\
$\mathbf{C}$ & $1.89 \pm 1.05$ & $\mathrm{NC}$ & $0.4(0.2-0.7)$ & $9.0(7.2-10.0)$ \\
$\mathbf{D}$ & $6.35 \pm 2.24$ & $\mathrm{NC}$ & $1.3(1.1-1.5)$ & $14.3(13.3-15.5)$ \\
$\mathbf{E}$ & $2.75 \pm 1.42$ & $\mathrm{NC}$ & $1.2(1.0-1.4)$ & $13.5(12.2-15.0)$ \\
$\mathbf{F}$ & $0.35 \pm 0.8$ & $1.1(0.7-1.6)$ & $3.0(2.2-4.0)$ & $25.0(18.5-33.0)$ \\
\hline
\end{tabular}

\section{RESULTS}

\section{Interespecific differences in growth under uranium exposure}

A. tetracladia grew faster $\left(2.29 \mathrm{~mm}^{2} / \mathrm{d}\right)$ under control conditions, while $V$. elodeae grew slowest (0.88 $\mathrm{mm}^{2} / \mathrm{d}$; Fig. 1) among the four species of aquatic hyphomycetes. Mycelial growth differed among species $\left(F_{3,15}=97.28 ; p<0.001\right)$, and uranium concentrations $\left(F_{5,15}=409.07 ; p<\right.$ 0.001), Table S2, available at http://www.limnetica. net/en/limnetica. The uranium concentration causing $50 \%$ mycelial growth inhibition $\left(\mathrm{EC}_{50}\right)$ ranged from 12.5 to $45 \mathrm{mg} / \mathrm{l}$ (Table 1), with $A$. tetracladia the most sensitive and $V$. elodeae the most tolerant species. A uranium concentration of $0.85 \mathrm{mg} / \mathrm{l}$ was enough to cause a $20 \%$ reduction in growth in $A$. tetracladia, while the same $20 \%$ inhibition in $H$. lugdunensis occurred at $3 \mathrm{mg} / 1$. At the lower uranium concentrations $(<1 \mathrm{mg} / \mathrm{l})$, T. splendens and $H$. lugdunensis grew up to $12 \%$ faster than the control (Table S3, available at http://www.limnetica.net/en/limnetica).

\section{Differences between strains of $\boldsymbol{H}$. lugdunensis}

Mycelial growth differed between strains $\left(F_{5,25}=\right.$ 88.93; $p<0.001)$, and uranium concentrations $\left(F_{525}=879.57 ; p<0.001\right)$, Table S4, available at http://www.limnetica.net/en/limnetica. Under control conditions (no uranium) growth in agar 
plates ranged from $1.26 \mathrm{~mm}^{2} / \mathrm{d}$ (Strain $\mathrm{D}$, from the most contaminated site) to $1.89 \mathrm{~mm}^{2} / \mathrm{d}$ (Strain A) (Fig. 2). Inhibition was unrelated to the origin of the strains (Tables 2 and S5, available at http://www.limnetica.net/en/limnetica). Under increasing uranium concentrations, the strain from the most polluted site (D) grew more slowly than the others and was one of the less tolerant strains. The strain from the reference site (F) was more tolerant than the others. The most sensitive strain (C), determined by its low ECs and TI values was sampled from a site with comparatively low uranium concentration.

\section{Colony morphology}

Colony morphology differed among strains and concentrations. The colonies grew with a regular boundary for all strains and uranium concentrations $<1 \mathrm{mg} / \mathrm{l}$. At the highest concentrations, boundaries became whitish and irregular. Strain colonies were brown-orange under low uranium concentrations but acquired irregular boundaries under 16 and $262 \mathrm{mg} / \mathrm{l}$ (Fig. 3).

\section{Sporulation rates, fungal biomass and leaf- litter decomposition in microcosms}

The $\mathrm{pH}$ in the microcosms averaged $7.3 \pm 0.7$ except for uranium concentration of $262 \mathrm{mg} / 1$, where the $\mathrm{pH}$ was $4.8 \pm 0.3$. Under control condi-

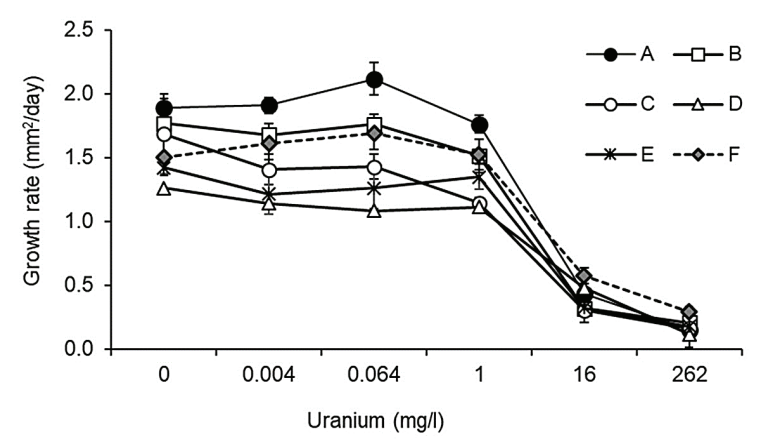

Figure 2. Growth ( $\mathrm{mm}^{2} /$ day) of six Heliscus lugdunensis strains in agar plates under six uranium concentrations (mean \pm standard deviation; $\mathrm{n}=3)$. Crescimento $\left(\mathrm{mm}^{2} /\right.$ day) de seis estirpes de Heliscus lugdunensis em placas de Petri sob seis concentrações de urânio (média \pm desvio padrão; $n=3$ ). tions, average spore production ranged from 86 (A. tetracladia) to 3,138 spores per mg dry mass (H. lugdunensis) (Fig. 4). Under low uranium concentration (up to $0.064 \mathrm{mg} / \mathrm{l}$ ), sporulation rates were stimulated in some species, but inhibited at concentrations above $1 \mathrm{mg} / 1$ ( $V$. elodeae) and $262 \mathrm{mg} / \mathrm{l}$ (H. lugdunensis). At $262 \mathrm{mg} / \mathrm{l}$, T. splendens and $A$. tetracladia demonstrated $64 \%$ and $100 \%$ of inhibition in sporulation when compared to control, respectively (Fig. 4).

Fungal biomass in leaf discs under control conditions ranged from 18 (H. lugdunensis) to 23 ( $V$. elodeae) $\mathrm{mg} / \mathrm{g}$ DM. Fungal biomass was reduced by uranium at concentrations of $16 \mathrm{mg} / 1$ (T. splendens and H. lugdunensis) and $262 \mathrm{mg} / 1$ (A. tetracladia) (Fig. 5). Leaf-litter decomposition was reduced by $16 \mathrm{mg} / 1$ for all species, except for $A$. tetracladia (Fig. 6). Average litter decomposition ranged from $15.2 \pm 0.6 \%$ ( $T$. splendens) to $23.9 \pm 0.1 \%$ (H. lugdunensis) for control conditions (no uranium); and $6.3 \pm 2.0 \%$ (T. splendens) to $8.9 \pm 6.1 \%$ ( V. elodeae $)$ for the highest uranium concentration $(262 \mathrm{mg} / \mathrm{l})$. After 24 days in the microcosms, the leaf discs had increased levels of uranium according to concentrations in the solutions tests (Fig. 7), up to 89 $\mathrm{mg} / \mathrm{kg}$ in $262 \mathrm{mg} / \mathrm{l}$.

\section{DISCUSSION}

We found that, in general, uranium concentrations below $1 \mathrm{mg} / \mathrm{l}$ caused no significant inhibition of fungal growth, sporulation, biomass or leaf-litter decomposition. Inhibition was observed at uranium concentration ranging from 1 to $262 \mathrm{mg} / \mathrm{l}$, depending on the species. According to this data, some of the sampled streams from which $H$. lugdunensis strains were obtained are slightly polluted $(0.35-6.35 \mu \mathrm{g} / 1)$. Moreover, Bergmann et al. (2018) reported that $95 \%$ of the 298 sites receiving waters from deactivated uranium mines in Portugal had $<10 \mu \mathrm{g} / 1$, while $1.3 \%$ had $>100 \mu \mathrm{g} / 1$, and $0.33 \%>1000 \mu \mathrm{g} / \mathrm{l}$. Our findings indicate that some of those streams may exhibit ecological impairment.

In our experiments, uranium concentrations of $0.4-9 \mathrm{mg} / 1$ inhibited mycelial growth in $20 \%$ to $50 \%$ (Table 2). It is apparent that aquatic hyphomycetes are less tolerant to uranium than 

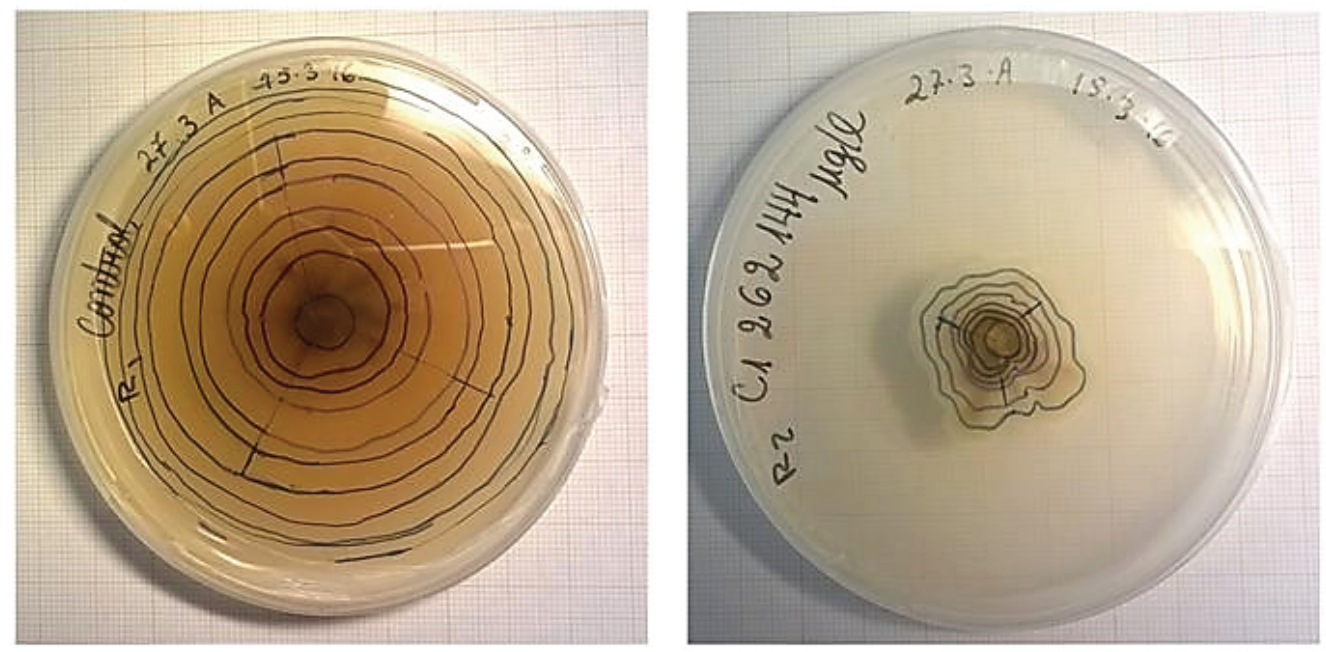

Figure 3. Colony morphology of Heliscus lugdunensis (strain A) grown under control (no uranium) (left) and under $262 \mathrm{mg} / \mathrm{l}$ of uranium (right). At high uranium concentration the colony edge becomes irregular and has a different color (lines indicate the weekly increases in area). Morfologia da colónia de Heliscus lugdunensis (estirpe A) crescida sem adição de urânio (controle, esquerda) e sob concentração de $262 \mathrm{mg} / \mathrm{l}$ (direita). Em concentrações elevadas de urânio, as margens das colónias eram mais irregulates e com diferente coloração (as linhas indicam o crescimento semanal em área).

other fungi such as Aspergillus niger and Paecilomyces javanicus whose tolerance indices ranged from 20 to $28 \%$ in $10 \mathrm{mM}$ uranium (400 $\mathrm{mg} / \mathrm{l}$ ) (Liang et al., 2015). Another example is the growth ability of Rhizopus arrihizus in 200 $\mathrm{mg} / \mathrm{l}$ that reflects its maximum biosorption capacity and removal of uranyl ions under acidic $\mathrm{pH}$ (Wang et al., 2010). On the other hand, aquatic hyphomycetes were more tolerant than the algae Chlorella sp whose growth was inhibited by $50 \%$ at $78 \mu \mathrm{g} / 1$ due to greater binding of uranium to the cell surface and its uptake into the cell (Franklin et al., 2000). Higher uranium concentrations such as $200 \mu \mathrm{M}(8 \mathrm{mg} / \mathrm{l})$ inhibited growth of the bacterial strains from subsurface sediments under experimental conditions (Brzoska \& Bollmann, 2016). These bacterial strains can survive well in the natural environment, however, even in the presence of metals contaminants probably due to their ability to denitrify and consequently to be less susceptible to toxic effects of uranium (Brzoska \& Bollmann, 2016). Compared with aquatic invertebrates, values similar to the lowest inhibition rates in this study ( $\sim 1 \mathrm{mg} / 1$, EC10) caused $50 \%$ immobility for $D$. magna (1.4 mg/1) (Antunes et al., 2007) or 50\% mortality in Hyalella azteca (LC50; $1.52 \mathrm{mg} / \mathrm{l})$ (Kuhne et al., 2002).

Fungal reproduction is one of the parameters most sensitive to metal contamination (Gessner \& Chauvet, 1997; Duarte et al., 2004). Fungal biomass was significantly reduced here at 262 $\mathrm{mg} / \mathrm{l}$ for $A$. tetracladia, whereas sporulation was inhibited for this same species and for $V$. elodeae from $1 \mathrm{mg} / 1$ (Fig. 4).

Conidia production has been correlated to aquatic hyphomycete decomposition activity (Duarte et al., 2004). Aquatic hyphomycetes can allocate $\sim 50 \%$ of their total production to conidia with a proportional average of the total leaf-litter mass loss (Gessner \& Chauvet, 1997). As with sporulation and biomass, leaf-litter decomposition was also reduced $(\sim 46-58 \%)$ in the 16 and/or $262 \mathrm{mg} / \mathrm{l}$ of uranium for three of the four species in relation to control/no uranium exposure. The mechanism causing inhibition is not known, but it is possible that aquatic hyphomycetes enzymes become nonfunctional under metal exposure, interfering with degradative activities and consequently also with leaf-litter mass loss (Sridhar et al., 2001).

The increased accumulation/biosorption of 
uranium in leaf discs across concentrations may change the physical structure of leaf discs tissues (Ding et al., 2012) and may have limited the availability of oxygen and inorganic compounds for the mycelia (Sridhar et al., 2001). The reduction in
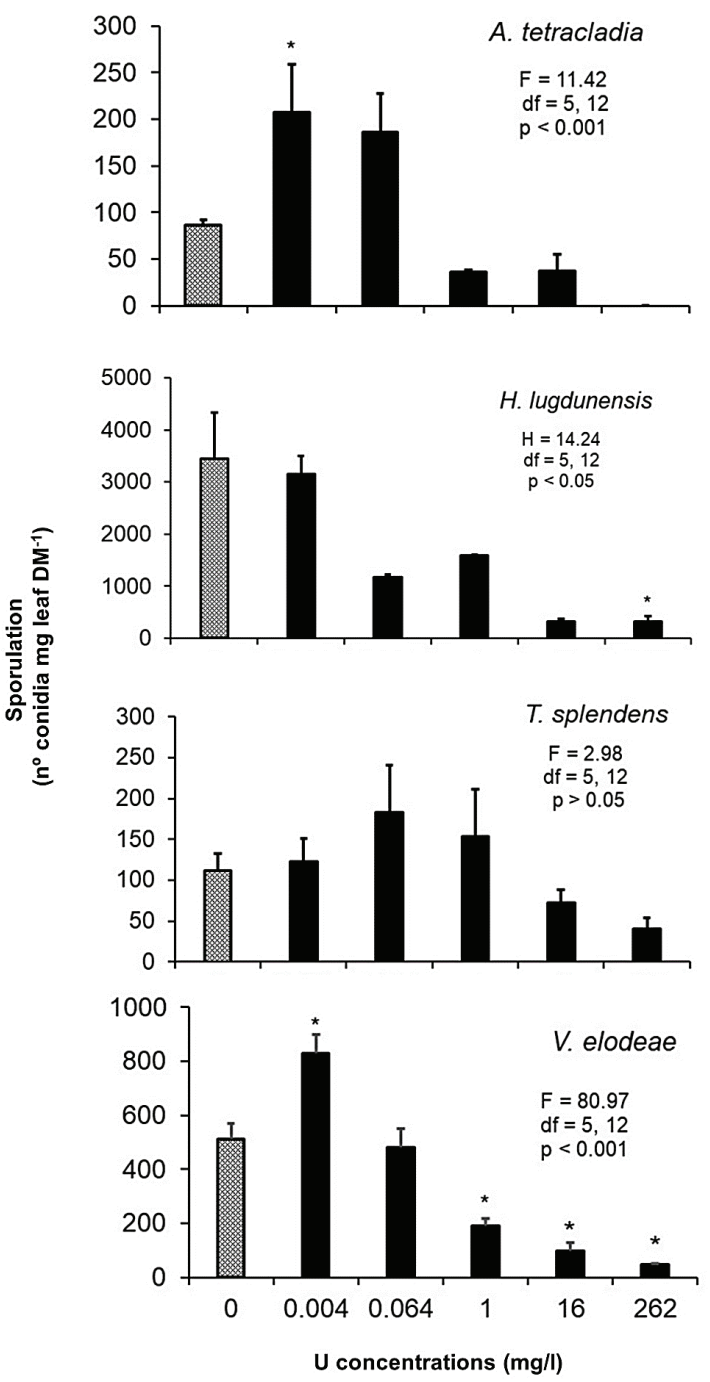

Figure 4. Cumulative conidia production of four aquatic hyphomycetes species (mean \pm standard error) growing in leaves exposed to increased uranium concentrations for 24 days; $n=3$; one-way ANOVA followed by Holm-Sidak test against the control, or Rank ANOVA followed by Dunn's Method; * = $p<0.05$. Produção cumulativa de esporos por quatro espécies de hifomicetos aquáticos (média \pm erro padrão) em discos foliares expostos a concentrações crescentes de urânio durante 24 dias; $\mathrm{n}=3$; ANOVA de uma via e análise post-hoc contra o grupo controle (Holm-Sidak), ou Rank ANOVA e teste de Dunn: $*=\mathrm{p}<0.05$. sporulation and leaf-litter decomposition in our experiment indicated a pronounced decrease in the allocation of resources (energy and material) for conidia production at higher uranium exposure (Duarte et al., 2008). Under higher uranium

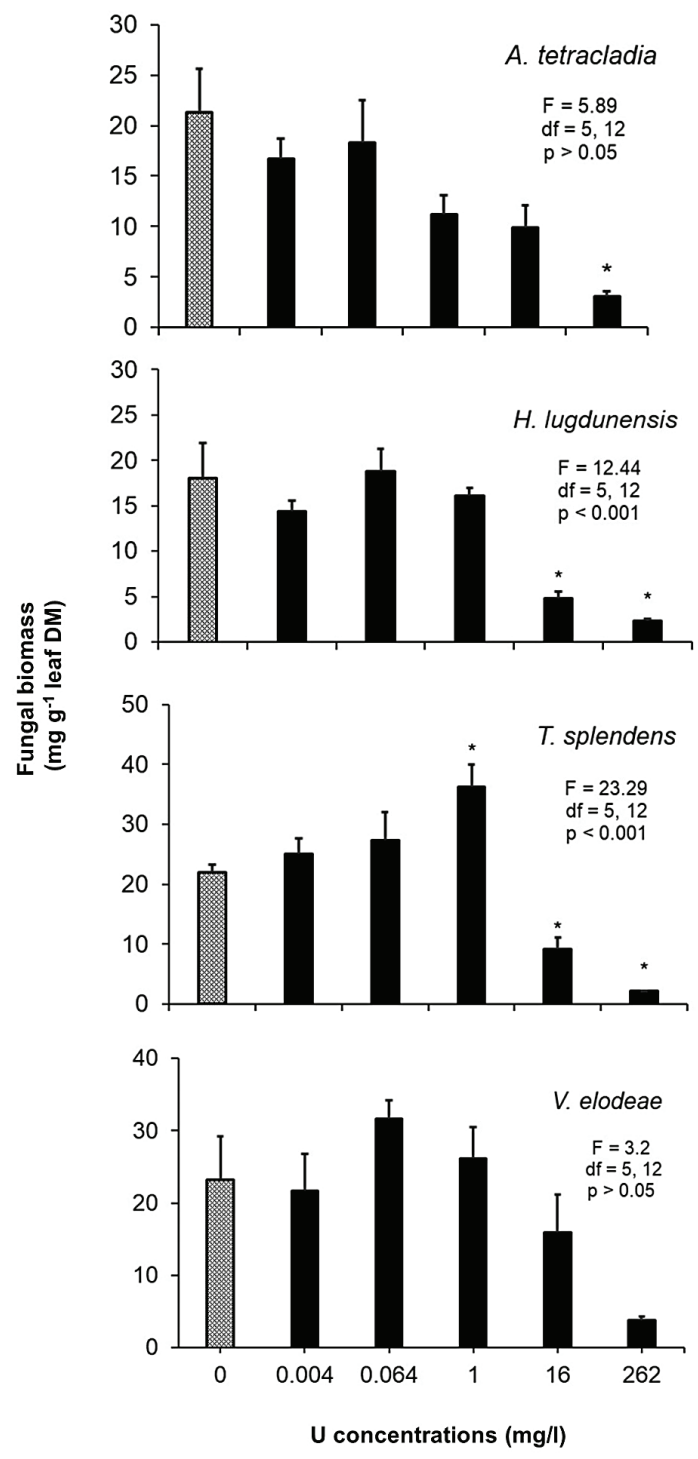

Figure 5. Fungal biomass of four aquatic hyphomycetes species (mean \pm standard error) growing in leaves exposed to increased uranium concentrations for 24 days; $n=3$; one-way ANOVA followed by Holm-Sidak test against the control; * $=p<0.05$. Biomassa de quatro espécies de hifomicetos aquáticos (media \pm erro padrão) em discos foliares expostos a concentrações crescentes de urânio durante 24 dias; $\mathrm{n}=3 ;$ ANOVA de uma via e análise post-hoc contra o grupo controle (Holm-Sidak); * $=\mathrm{p}$ $<0.05$. 
concentration, however, $\mathrm{pH}$ was also low due to the larger amount of uranyl ions $\left(\mathrm{UO}_{2}{ }^{2+}\right)($ Alam \& Cheng, 2014). It is difficult to predict how acidity could have affected sporulation, especially for $A$. tetracladia, $H$. lugdunensis and $V$. elodeae, although the latter had already decreased spore production in concentration of $16 \mathrm{mg} / \mathrm{l}$. Low $\mathrm{pH}$ $(<5)$ has been shown to decrease litter decomposition in acidic streams (Cornut et al., 2012; Ferreira \& Guérold, 2017), by reducing the abundance and biomass of the sensitive shredders (Dangles \& Guérold, 2001), a reduction of microbial activity (Dangles et al., 2004), and a decrease in aquatic hyphomycetes biomasses and species (Baudoin et al., 2008). Not all these factors for the reduction in leaf mass loss under acidic conditions were present in the laboratory but is possible that cell wall components degradation was inhibited by acidification (Kok et al., 1992).

Low uranium concentrations stimulated fungal growth, biomass and sporulation by aquatic hyphomycetes in some species. This observation is consistent with a large body of literature relating pollutants to biological processes, and is known as hormesis. Hormesis occurs when a stressor causes noxious effects in a biological system at high concentration, but it causes the enhancement of a biological parameter at low quantity (Calabrese \& Baldwin, 2001). As in the mycelial growth assay for some species, conidia production was also stimulated at low uranium concentrations in $A$. tetracladia and $V$. elodeae (Fig. 4). The faster growth for the lower uranium concentrations tested, however, may reveal the capacity of fungi to deal with metals. Fungal biomass may biosorb up to $600 \mathrm{mg} / \mathrm{g}$ dry weight for uranium from aqueous solutions (Ogar et al., 2014). Uranium adsorption by A. tetracladia mycelium was $140 \mathrm{mg} / \mathrm{g}$ dry weight at $2000 \mu \mathrm{g} / \mathrm{l}$, indicating that native hyphomycetes can retrieve the metal from the stream water (Ferreira et al., 2010). Due to the biosorption kinetics, fungal hyphae can excrete organic acids that bind to uranium particles, and extracellular uranium can be precipitated (Fomina et al., 2008; Krauss et al., 2011). It is also possible that uranium was accumulated into vacuoles in the older cells of fungal hyphae, allowing tip cells differentiation and growth even in a metal contaminated media (Isaure et al., 2017).
High uranium concentrations caused an inhibition of fungal growth, biomass, sporulation and leaf-litter decomposition. The growth inhibition observed at the highest $\mathrm{U}$ concentrations indicates toxicity. High uranium concentration
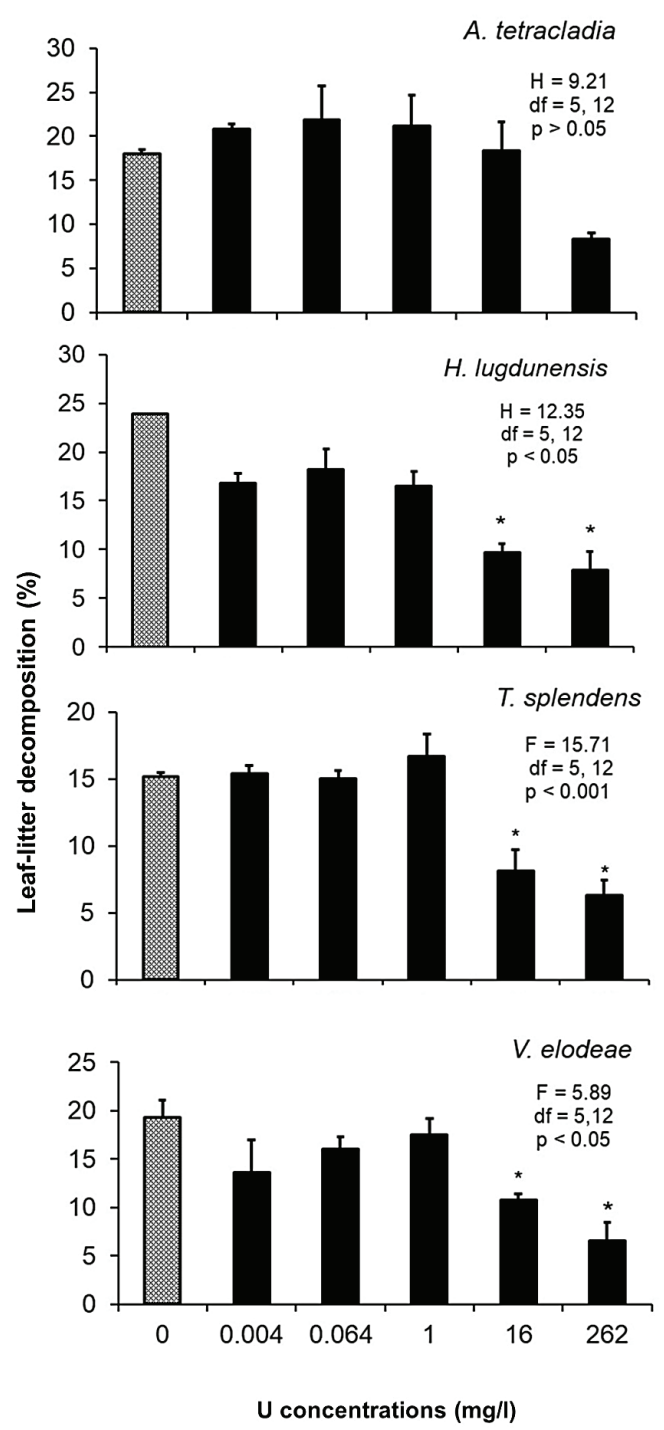

Figure 6. Leaf-litter decomposition for the four aquatic hyphomycetes species (mean \pm standard error) growing in leaves exposed to increased uranium concentrations for 24 days; $n=3$; one-way ANOVA followed by Holm-Sidak test against the control, or Rank ANOVA followed by Dunn's Method; * $=p<$ 0.05. Decomposição foliar para quatro espécies de hifomicetos aquáticos (média \pm erro padrão) em discos foliares expostos a crescentes concentrações de urânio durante 24 dias; $\mathrm{n}=3$; ANOVA de uma via e análise post-hoc contra o grupo controle (Holm-Sidak), ou Rank ANOVA e teste de Dunn: * ${ }^{*} \mathrm{p}<0.05$. 
potentially changes the surface of fungal cells (Zheng et al., 2017) which may explain the changed colonies morphology and decreasing growth. Uranyl ions bind to cell walls, precipitate with phosphates and can accumulate intracellularly (Strandberg et al., 1981). The low pH observed in our experiment for $262 \mathrm{mg} / \mathrm{l} \mathrm{might}$ have favoured uranium biosorption by fungi (Bayramoğlu et al., 2006).

Overall, the uranium tolerance of H. lugdunensis strains was found to be independent of the level of pollution at the site of origin. This was unexpected, since stressing conditions should select genotypes capable of copping with new conditions (here, metal pollution), and the most sensitive genotypes should be eliminated. Aquatic hyphomycetes produce a large number of spores which are transported downstream by the current and may attach to organic matter where conditions are different from those of the site where they are produced $(\sim 1.8 \mathrm{~km}$; Fabre, 1997). A polluted site may thus be continuously being colonised by genotypes produced upstream (and not exposed) of the contamina- tion. In this same way, conidia produced at a polluted site may be transported away from the polluted site.

\section{CONCLUSION}

Growth, sporulation, biomass and leaf mass loss were significant at uranium concentrations $>1$ $\mathrm{mg} / \mathrm{l}$. There are interspecific differences in fungal sensitivity to uranium. Finally, the performance of $H$. lugdunensis strains was independent of pollution levels at the site of origin, suggesting differences in aquatic hyphomycetes sensitivity.

\section{ACKNOWLEDGEMENTS}

The authors thank Olimpia Sobral, Ana Pereira and Verónica Ferreira for assistance in several steps of the experiments. We thank also Seena Sahadevan and the project DiverseAquaFun (PTDC/AAG-GLO/3896/2012) for kindly providing the $H$. lugdunensis strains cultures from polluted sites. This study was supported by the Portuguese Foundation for Science and Technolo-

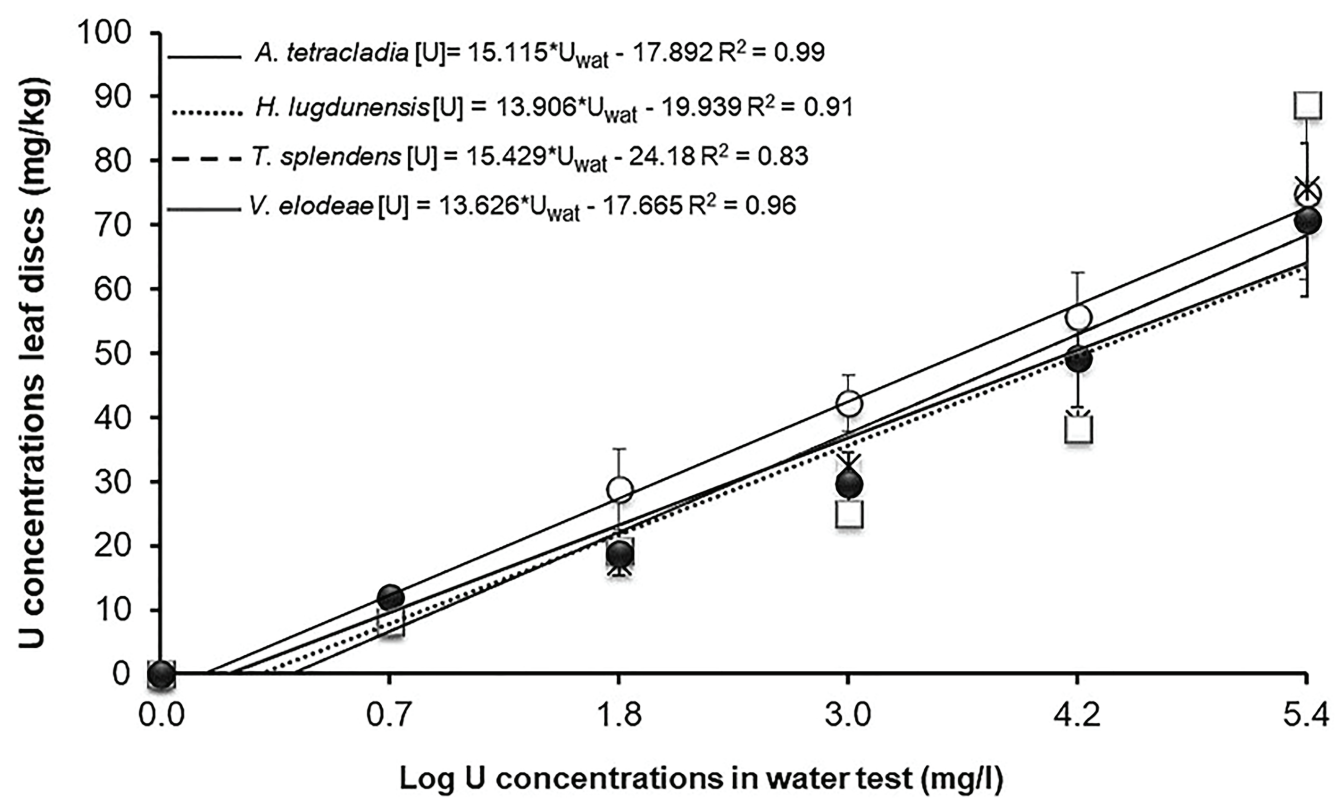

OA. Tetracladia

*H. lugdunensis

$\square T$. splendens

OV. elodeae

Figure 7. Amounts of uranium in alder leaves exposed to increased concentrations of the metal (mean \pm standard error), $n=3$. Quantidade de urânio em folhas de amieiro expostas a crescentes concentrações do metal (média \pm erro padrão); $\mathrm{n}=3$. 
gy (FCT) through the strategic project UID/MAR/ 04292/2013 granted to MARE. Melissa Bergmann was supported by the National Council for Technological and Scientific Development (CNPq) (GDE 206450/2014-1).

\section{REFERENCES}

ALAM, M. S. \& T. CHENG. 2014. Uranium release from sediment to groundwater: Influence of water chemistry and insights into release mechanisms. Journal of Contaminant Hydrology, 164: 72-87. DOI: 10.1016/j.jconhyd.2014. 06.001

ANTUNES, S. C., D. R. DE FIGUEIREDO, S. M., MARQUES, B. B. CASTRO, R. PEREIRA \& F. GONÇALVES. 2007. Evaluation of water column and sediment toxicity from an abandoned uranium mine using a battery of bioassays. Science of the Total Environment, 374: 252-259. DOI: 10.1016/j.scitotenv.2006. 11.025

BALDRIAN, P. \& J. GABRIEL. 2002. Intraspecific variability in growth response to cadmium of the wood-rotting fungus Piptoporus betulinus. Mycologia, 94: 428. DOI: 10.2307/ 3761777

BÄRLOCHER, F. 2005. Sporulation by aquatic hyphomycetes, In: Methods to Study Litter Decomposition: A Practical Guide. M.A.S. Graça, F. Bärlocher \& M.O. Gessner (eds.): 185 - 188, Springer Netherlands.

BÄRLOCHER, F. (ed.). 2012. The ecology of aquatic hyphomycetes. Springer-Verlag Berlin Heidelberg. DOI: 10.1007/978-3-64276855-2

BAUDOIN, J. M., F. GUÉROLD, V. FELTEN, E. CHAUVET, P. WAGNER \& P. ROUSSELLE. 2008. Elevated aluminium concentration in acidified headwater streams lowers aquatic hyphomycete diversity and impairs leaf-litter breakdown. Microbial Ecology, 56: 260-269. DOI: 10.1007/s00248-007-9344-9

BAYRAMOGLU, G., G. ÇELIK, G. \& M. Y. ARICA. 2006. Studies on accumulation of uranium by fungus Lentinus sajor-caju. Journal of Hazardous Materials, 136: 345-353. DOI: 10.1016/j.jhazmat.2005.12.027.

BERGMANN, M., O. SOBRAL, J. PRATAS \&
M. A. S. GRAÇA. 2018. Uranium toxicity to aquatic invertebrates: A laboratory assay. Environmental Pollution, 239: 359-366. DOI: 10.1016/j.envpol.2018.04.007

BRAHA, B., H. TINTEMANN, G. KRAUSS, J. EHRMAN, F. BÄRLOCHER \& G. J. KRAUSS. 2007. Stress response in two strains of the aquatic hyphomycete Heliscus lugdunensis after exposure to cadmium and copper ions. BioMetals, 20: 93-105. DOI: 10.1007/s10534-006-9018-y

BRZOSKA, R. M. \& A. BOLLMANN. 2016. The long-term effect of uranium and $\mathrm{pH}$ on the community composition of an artificial consortium. FEMS Microbiology Ecology, 92: 1-8. DOI: 10.1093/femsec/fiv158

CALABRESE, E. J. \& L. A. BALDWIN, L. A. 2001. Hormesis: A generalizable and unifying hypothesis. Critical Reviews in Toxicology, 31: 353-424.

CHUNG, N. \& K. SUBERKROPP. 2009. Contribution of fungal biomass to the growth of the shredder, Pycnopsyche gentilis (Trichoptera: Limnephilidae). Freshwater Biology, 54: 2212-2224. DOI: 10.1111/j.1365-2427.2009. 02260.x

CORNuT, J., H. Clivot, E. CHAUVET, A. ELGER, C. PAGNOUT \& F. GUÉROLD. 2012. Effect of acidification on leaf litter decomposition in benthic and hyporheic zones of woodland streams. Water Research, 46: 6430-6444. DOI: 10.1016/j.watres.2012.09.023

DANGLES, O. \& F. GUÉROLD. 2001. Linking shredders and leaf litter processing: Insights from an acidic stream study. International Review of Hydrobiology, 86: 395-406. DOI: 10.1002/1522-2632(200107)86:4/5

DANGLES, O., M. O. GESSNER, F. GUÉROLD \& E. CHAUVET. 2004. Impacts of stream acidification for assessing ecosystem functioning implications. Journal of Applied Ecology, 41: 365-378.

DESCALS, E. 2005. Techniques for handling ingoldian fungi. In: Methods to Study Litter Decomposition: A Practical Guide. M.A.S. Graça, F. Bärlocher \& M.O. Gessner (eds.): 129 - 141. Springer Netherlands.

DING, D. X., X. T. LIU, N. HU, G. Y. LI \& Y. D. WANG. 2012. Removal and recovery of 
uranium from aqueous solution by tea waste. Journal of Radioanalytical and Nuclear Chemistry, 293: 735-741. DOI: 10.1007/ s10967-012-1866-z

DUARTE, S., C. PASCOAL \& F. CÁSSIO. 2004. Effects of zinc on leaf decomposition by fungi in streams: Studies in microcosms. Microbial Ecology, 48: 366-374. DOI: 10.1007/s00248-003-2032-5

DUARTE, S., C. PASCOAL, A. ALVES, A. CORREIA \& F. CÁSSIO. 2008. Copper and zinc mixtures induce shifts in microbial communities and reduce leaf litter decomposition in streams. Freshwater Biology, 53: 91-101. DOI: $10.1111 /$ j.1365-2427.2007.01869.x

FABRE, E. 1997. Changes in concentration of aquatic hyphomycete conidia in water passing through a concrete pipe. Mycological Research, 101: 908-910. DOI: 10.1017/ S0953756297003948

FERREIRA, V., A.L. GONÇALVES, J. PRATAS \& C. CANHOTO. 2010. Contamination by uranium mine drainages affects fungal growth and interactions between fungal species and strains. Mycologia, 102: 1004-1011. DOI: 10.3852/09-248

FERREIRA, V. \& F. GUÉROLD. 2017. Leaf litter decomposition as a bioassessment tool of acidification effects in streams: Evidence from a field study and meta-analysis. Ecological Indicators, 79: 382-390. DOI: 10.1016/j. ecolind.2017.04.044

FOMINA, M., J. M. CHARNOCK, S. HILLIER, R. ALVAREZ \& G. M. GADD. 2007. Fungal transformations of uranium oxides. Environmental Microbiology, 9: 1696-1710. DOI: 10.1111/j.1462-2920.2007.01288.x

FOMINA, M., J. M. CHARNOCK, S. HILLIER, R. ALVAREZ, F. LIVENS \& G. M. GADD. 2008. Role of fungi in the biogeochemical fate of depleted uranium. Current Biology, 18: 375-377. DOI: 10.1016/j.cub.2008.03.011

FRANKLIN, N. M., J. L. STAUBER, S. J. MARKICH \& R. P. LIM. 2000. pH-dependent toxicity of copper and uranium to a tropical freshwater alga (Chlorella sp.). Aquatic Toxicology, 48: 275-289. DOI: 10.1016/S0166-445X(99) 00042-9

GESSNER, M. O. \& E. CHAUVET. 1997.
Growth and production of aquatic hyphomycetes in decomposiing leaf litter. Limnology and Oceanography, 42: 496-505. DOI: 10.4319/1o.1997.42.3.0496

GESSNER, M. O. 2005. Ergosterol as a measure of fungal biomass. In: Methods to Study Litter Decomposition: A Practical Guide. M.A.S. Graça, F. Bärlocher \& M.O. Gessner (eds.): 189 - 195, Springer Netherlands.

GESSNER, M. O., V. GULIS, K. A. KUEHN, E. CHAUVET \& K. SUBERKROPP. 2007. Fungal decomposers of plant litter in aquatic ecosystems. In: The Mycota - Environmental and Microbial Relationships. C.P. Kubicek, I.S. Druzhinina (ed.): 301-324. Springer, Berlin Heidelberg.

GESSNER, M. O. \& E. CHAUVET. 1993. Ergosterol-to -biomass conversion factors for aquatic hyphomycetes. Applied and Environmental Microbiology, 59: 502-507. https://aem. asm.org/content/aem/59/2/502.full.pdf

GONÇALVES, A. L., A.V. LÍRIO, J. PRATAS \& C. CANHOTO. 2011. Uranium contaminated water does not affect microbial activity but decreases feeding by the shredder Sericostoma vittatum. Fundamental and Applied Limnology/Arch. für Hydrobiologie, 179: 17-25. DOI: 10.1127/1863-9135/2011/0179-0017

HYNE, R. V., G. D. RIPPON \& G. ELLENDER. 1993. Investigation of Uranium-induced toxicity in freshwater Hydra. In: Ecotoxicology of Metals in Invertebrates. R. Dallinger, P. Rainbow (eds.). Lewis Publishers.

ISAURE, M. P., B. LEYH, M. SALOMÉ, G. J. KRAUSS, D. SCHAUMLÖFFEL \& D. DOBRITZSCH. 2017. The aquatic hyphomycete Heliscus lugdunensis protects its hyphae tip cells from cadmium: A micro X-ray fluorescence and X-ray absorption near edge structure spectroscopy study. Spectrochimica Acta - Part B Atomic Spectroscopy, 137: 85-92. DOI: 10.1016/j.sab.2017.09.012

KOK, C. J., W. HAVERKAMP \& H. A. VAN DER AA. 1992. Influence of $\mathrm{pH}$ on the growth and leaf-maceration ability of fungi involved in the decomposition of floating leaves of Nymphaea alba in an acid water. Journal of General Microbiology, 138: 103-108. DOI: 10.1099/00221287-138-1-103 
KRAUSS, G., F. BÄRLOCHER, P. SCHRECK, R. WENNRICH, W. GLÄSSER \& G. J. KRAUSS. 2001. Aquatic hyphomycetes occur in hyperpolluted waters in Central Germany. Nova Hedwigia, 72: 419-428. DOI: 10.1127/NOVA.HEDWIGIA/72/2001/419

KRAUSS, G. J., M. SOLÉ, G. KRAUSS, D. SCHLOSSER, D. WESENBERG \& F. BÄRLOCHER. 2011. Fungi in freshwaters: Ecology, physiology and biochemical potential. FEMS Microbiology Reviews, 35: 620-651. DOI: $10.1111 /$ j.1574-6976.2011.00266.x

KUHNE, W. W., C. A. CALDWELL, W. R.GOULD, P. R. FRESQUEZ \& S. FINGER. 2002. Effects of depleted uranium on the health and survival of Ceriodaphnia dubia and Hyalella azteca. Environmental Toxicology and Chemistry, 21: 2198-2203. DOI: 10.1002/etc.5620211025

LIANG, X., S. HILLIER, H. PENDLOWSKI, N. GRAY, A. CECI \& G. M. GADD. 2015. Uranium phosphate biomineralization by fungi. Environmetal Microbiology, 17: 2064-2075. DOI: 10.1111/1462-2920.12771

MAHARNING, A. R. \& F. BÄRLOCHER. 1996. Growth and Reproduction in Aquatic Hyphomycetes. Mycologia, 88: 80-88.

MEDEIROS, A. O., P. ROCHA, C. A. ROSA \& M. A. S. GRAÇA. 2008. Litter breakdown in a stream affected by drainage from a gold mine. Fundamental and Applied Limnology /Arch. für Hydrobiologie, 172: 59-70. DOI: 10.1127/1863-9135/2008/0172-0059

MEDEIROS, A., S. DUARTE, C. PASCOAL, F. CÁSSIO \& M. A. S. GRAÇA. 2010. Effects of $\mathrm{Zn}, \mathrm{Fe}$ and $\mathrm{Mn}$ on leaf litter breakdown by aquatic fungi: A microcosm study. International Review of Hydrobiology, 95: 12-26. DOI: 10.1002/iroh.200911182

MIERSCH, J., F. BARLOCHER, I. BRUNS \& G. J. KRAUSS. 1997. Effects of cadmium, copper, and zinc on growth and thiol content of aquatic hyphomycetes. Hydrobiologia, 346: 77-84. DOI: 10.1023/A:1002957830704

MUSCATELLO, J. R. \& K. LIBER. 2009. Accumulation and chronic toxicity of uranium over different life stages of the aquatic invertebrate Chironomus tentans. Archives of Environmental Contamination and Toxicology, 57:
531-539. DOI: 10.1007/s00244-009-9283-1

OECD, 2003. Draft guidance document for on the statistical analysis of ecotoxicity data (Technical Report). Environment Directorate Organization for Economic Co-operation and Development, Paris.

OGAR, A., A. GRANDIN, V. SJÖBERG, K. TURNAU \& S. KARLSSON. 2014. Stabilization of Uranium(VI) at low $\mathrm{pH}$ by fungal metabolites: Applications in environmental biotechnology. APCBEE Procedia, 10: 142-148. DOI: 10.1016/j.apcbee.2014.10.032 PEREIRA, R., S. BARBOSA \& F. P. CARVALHO. 2014. Uranium mining in Portugal: A review of the environmental legacies of the largest mines and environmental and human health impacts. Environmental Geochemistry and Health, 36: 285-301. DOI: 10.1007/ s10653-013-9563-6

PRADHAN, A., S. SEENA, D. DOBRITZSCH, S. HELM, K. GERTH, M. DOBRITZSCH, G. J. KRAUSS, D. SCHLOSSER, C. PASCOAL \& F. CÁSSIO. 2014. Physiological responses to nanoCuO in fungi from non-polluted and metal-polluted streams. Science of the Total Environment, 466-467: 556-563. DOI: 10.1016/j.scitotenv.2013.07.073

PRADHAN, A., S. SEENA, D. SCHLOSSER, K. GERTH, S. HELM, M. DOBRITZSCH, G. J. KRAUSS, D. DOBRITZSCH, C. PASCOAL \& F. CÁSSIO. 2015. Fungi from metal-polluted streams may have high ability to cope with the oxidative stress induced by copper oxide nanoparticles. Environmental Toxicology and Chemistry, 34: 923-930. DOI: 10.1002/etc.2879

SRIDHAR, K. R., G. KRAUSS, F. BÄRLOCHER, N. S. RAVIRAJA, R. WENNRICH, R. BAUMBACH \& G. J. KRAUSS. 2001. Decomposition of alder leaves in two heavy metal-polluted streams in central Germany. Aquatic Microbial Ecology, 26: 73-80. DOI: 10.3354/ame026073

STRANDBERG, G. W., S. E. SHUMATE \& J. R. PARROT. 1981. Microbial Cells as Biosorbents for Heavy Metals: Accumulation of uranium by Saccharomyces cerevisiae and Pseudomonas aeruginosa. Applied Environmental Microbiology, 41: 237-245.

SUBERKROPP, K. \& T. L. ARSUFFI. 1984. 
Degradation, growth, and changes in palatability of leaves colonized by six aquatic hyphomycete species. Mycologia, 76: 398-407.

TAGLIAFERRO, M., A. M. M. GONÇALVES, M. BERGMAN, O. SOBRAL, O. \& M. A. S. GRAÇA. 2018. Assessment of metal exposure (uranium and copper) by the response of a set of integrated biomarkers in a stream shredder. Ecological Indicators, 95: 991-1000 DOI: 10.1016/j.ecolind.2017.10.065

UNITED NATIONS. 2015. Adoption of the Paris Agreement, 21st Conference of the Parties (Report).

VAN LOON, J. C.\& R. R.BAREFOOT. 1989.
Analytical methods for geochemical exploration. San Diego: Academic Press.

WANG, J., X. HU, J. WANG, Z. BAO, S. XIE \& Y. JINHUI. 2010. The tolerance of Rhizopus arrihizus to $\mathrm{U}(\mathrm{VI})$ and biosorption behavior of U(VI) onto R. arrihizus. Biochemical Engineering Journal, 51: 19-23. DOI: 10.1016/j. bej.2010.04.010

ZHENG, X. Y., X. Y. WANG, Y. H. SHEN, X. LU, T. S. WANG. 2017. Biosorption and biomineralization of uranium(VI) by Saccharomyces cerevisiae - Crystal formation of chernikovite. Chemosphere, 175: 161-169. DOI: 10.1016/j.chemosphere.2017.02.035

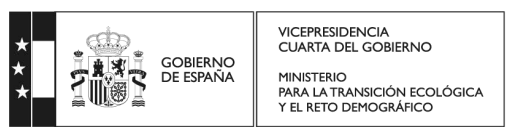

PARA LA TRANSICIÓN ECOLOGICA
YEL RETO DEMOGRAFICO

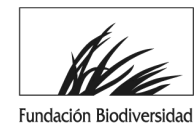

